\title{
THE EFFECT OF HYBRID DRYING (CONVECTIVE-MICROWAVE-ULTRASOUND) ON THE BIOACTIVE PROPERTIES OF OSMO-TREATED SOUR CHERRIES
}

\author{
Karolina CELEJEWSKA*, Monika MIESZCZAKOWSKA-FRĄC, Dorota KONOPACKA \\ Research Institute of Horticulture \\ Konstytucji 3 Maja 1/3, 96-100 Skierniewice, Poland
}

Received: December 2017; Accepted: April 2018

\begin{abstract}
The aim of the study was to assess the usefulness of hybrid drying methods (convective-microwave and convective-microwave-ultrasound) for sour cherry fruit preservation compared to convective drying. As the raw material, three sour cherry cultivars varying in quality characteristics ('Łutówka', 'Debreceni Bötermo', 'Nefris') were used. Before drying, fruits were subjected to osmotic treatment. Three different drying methods were examined: 1) convective (C), 2) hybrid with microwaves (C-MV) and 3) hybrid with microwaves and ultrasound (C-MV-US). As the quality indicators of the investigated processes, the changes in chemical composition, including alterations in the main groups of bioactive components, as well as in the antioxidant potential were monitored at each production stage. It was found that, when compared to convective drying, the use of the hybrid techniques allowed the drying time to be reduced from 9 to just 3 hours. Furthermore, employing hybrid drying eliminated the problems associated with the dehydration barrier observed during convective drying of the cultivar 'Debreceni Bötermo'. Regrettably, although the ultrasound used as the additional source of energy in the hybrid method slightly improved water evaporation, in general no significant effect on the retention of phenolic compounds was found. Irrespectively of the drying method, the effect of the cultivar proved to be crucial to the quality of the final product. Under the same processing conditions, 'Nefris' turned out to be the most promising cultivar for producing ready-to-eat fruit snacks of high nutritional value.
\end{abstract}

Key words: Prunus cerasus L., processing, sonication, quality, phenolic compounds

\section{INTRODUCTION}

Fruits and vegetables are a vital source of phytonutrients. There are numerous reports on the positive influence of consuming plant products on human health (Piasecka et al. 2013; Septembre-Malaterre et al. 2018). Among the red-colored fruits, sour cherries are one of the most valuable in terms of nutritional benefits resulting from their chemical composition (The Red Report 2012). Their consumption is very helpful in the prevention of life-style diseases, including cancer (Khoo et al. 2011). Such properties are directly linked with a high antiradical potential resulting from the presence of phenolic compounds, including a high percentage of anthocyanins. The latter ones, especially, are known to have significant medicinal properties, among others: cardiovascular disease prevention, anti-inflammatory, DNA damage protection, and enzymatic and lipid peroxidation inhibition (Damar \& Ekşi 2012; Bell et al. 2014; Wojdyło et al. 2014a; Braga et al. 2017). In the world of constant rush and stress, chronic diseases are increasingly diagnosed in ever younger people. An easy access to food products rich in antioxidants could contribute to their higher intake, so the effort of looking for a new assortment that would draw the attention of potential consumers to such products becomes justified (Sijtsema et al. 2012).

The outstanding phytonutrient profile of sour cherry fruits (Khoo et al. 2011; The Red Report 2012) qualifies this species to be called 'super fruit'. 
Unlike the fruit of other 'super species', such as blackcurrant or chokeberry, the sour cherry fruit is considered a delicacy because of its exceptional taste and aroma. However, very few sour cherry cultivars can be consumed fresh, as the acidic taste and short picking season for the majority of cherry cultivars necessitate fruit processing. An accurately designed and effective technological process makes it possible to conserve the bioactive compounds of sour cherry at a reasonably high level.

One of the potential preservation methods could be drying (Lewicki 2006; Kumar et al. 2014); however, to make the fruit suitable for direct consumption, an additional operation, such as osmotic treatment, is essential (Konopacka et al. 2009; Orrego et al. 2014). To produce dried sour cherries that might be acceptable for direct consumption as a snack, osmotic dehydration is needed to balance the sweet/sour taste as well as to obtain fine texture. This production step also helps to increase the dry matter content; however, it could lower the nutritional quality of the product by causing leakage of valuable hydrophilic compounds, such as anthocyanins. Literature data indicate that, depending on the cultivar, the anthocyanin content in ready-to-eat dried sour cherry snacks can range from 80 to as much as $320 \mathrm{mg}$ of anthocyanins in 100 grams of product (Konopacka \& Mieszczakowska-Frąc 2014). Also the choice of modern drying techniques, such as microwaves or ultrasound, can reduce the drying time or lower the process temperature, and thus contribute to better preservation of bioactive ingredients in the dried product (Wojdyło et al. 2014b; Calín-Sánchez 2015; Fan et al. 2017; Figiel \& Michalska 2017; Horuz et al. 2017; Onwude et al. 2017; Rodríguez et al. 2017). As the application of the microwave technique for drying of perishable fruits has been confirmed to be highly effective (Michalska et al. 2016; Zielinska \& Michalska 2016), the application of ultrasound in drying processes still remains at the experimental stage (Konopacka et al. 2015a). Recently, several experimental studies have been carried out in Poland, with the challenge of developing innovative hybrid dryer systems employing high-power ultrasound combined with microwave as well as convective drying methods (Konopacka \& Kowalski 2013). The positive effect of ultrasound assistance on the hybrid (microwaveconvective) drying technique has already been confirmed on a small experimental scale with apples (Kowalski \& Pawłowski 2015), strawberry (Szadzińska et al. 2016), raspberry (Kowalski et al. 2016), carrot (Kowalski et al. 2015; Konopacka et al. 2017), and green pepper (Szadzińska et al. 2017). A parallel hybrid drying system designed on a semitechnical scale, intended for the dehydration of highly adhesive biomaterials, specifically for the preservation of osmo-dehydrated fruit had been developed in the Research Institute of Horticulture (Patent No. PL 227427, 2017). In this device, the convection drying is assisted by microwave energy and an intense stream of ultrasound with an option to work in an intermittent drying mode. To ensure uniform contact between the applied energy and the material being dried, a process chamber was designed in the form of a rotary drum (Konopacka et al. 2015b). The preliminary drying tests of the device, carried out for osmo-dehydrated cherries and blueberries, proved the feasibility of reducing the drying time by half when compared to convective methods on trays. Surprisingly, the reduced drying time did not considerably increase the retention of anthocyanins (Konopacka et al. 2015b; Siucińska et al. 2015), while the preliminary character of the experiments did not provide sufficient data to explain the observed phenomena.

The aim of the study was to determine the suitability of the above-mentioned hybrid dehydration system for the production of dried sour cherry fruits with well retained bioactive properties. Three popular sour cherry cultivars with different physicochemical properties, previously subjected to osmotic treatment, were taken as a model of material rich in biologically active components and thus sensitive to thermal drying conditions. Special attention was paid to the effect of the ultrasound assistance, applied at the drying step on the changes in the pattern of sour cherry phenolic profile.

\section{MATERIALS AND METHODS}

The experiment was conducted on 3 sour cherry cultivars: 'Debreceni Bötermo' (DB), 'Nefris' (N) and 'Łutówka' (L) originating from the Experimental 
Orchard of the Research Institute of Horticulture in Dąbrowice (central Poland). Fruits were picked at the commercial maturity stage during the 2015 and 2016 harvesting seasons. Immediately after being transported, the fruits were cooled down at a temperature of $2{ }^{\circ} \mathrm{C}$ for $24 \mathrm{~h}$, then frozen and stored at $-25^{\circ} \mathrm{C}$ until processing.

\section{Osmotic dehydration}

Prior to the drying operation, the fruits were subjected to osmotic pretreatment chosen on the basis of previous experiments (Siucińska et al. 2016a, b) with some modifications. Before the osmotic dehydration $(\mathrm{OD})$, cherries were pitted in a frozen state $\left(-5^{\circ} \mathrm{C}\right)$. OD was carried out in a water bath fitted with a shaking plate $(67 \mathrm{rpm})$. Process temperature was adjusted to $40^{\circ} \mathrm{C}$ and lasted $120 \mathrm{~min}$. A sucrose solution $\left(60^{\circ} \mathrm{Bx}\right)$ was used as an osmotic agent. A 3000 -gram sample of fruits was divided equally between six $2 \mathrm{dm}^{3}$ glass beakers at a fruit-to-syrup ratio of $1: 2$. Every 30 minutes, the samples were stirred manually in order to provide periodic movement between the fruits and the solution, and thus to ensure a uniform concentration gradient. After osmotic dehydration, the fruits were rinsed with water to remove excess osmotic solution from the surface of the fruits, drained on a sieve, gently blotted on filter paper and subjected to final drying. For each drying method, a separate batch of osmo-dehydrated sour cherries was produced in two technological replications.

\section{Drying}

After the pretreatment stage, 1000 grams of osmotically dehydrated cherries were subjected to drying using three different methods: convective drying on trays (C) as the control and two versions of hybrid drying procedures carried out in a rotary drum. A workflow diagram of the experiment is presented in Figure 1. In the innovative hybrid drying method, combined convective and microwave power was used solely (C$\mathrm{MV}$ ) or with ultrasound assistance (C-MV-US).

The hybrid dryer allows application of various combinations of convection, ultrasound, microwave and chilling treatments. In the process, which lasted $180 \mathrm{~min}$, the cycles of heating $\left(60-80^{\circ} \mathrm{C}\right)$ were used either with or without the assistance of ultrasound $(200 \mathrm{~W})$ and microwaves (300 W) (Fig. 1). The hybrid drying procedure had been established by the authors after many experiments with the cultivar
'Nefris' (data mostly unpublished). The parameters of the classic convective drying were as follows: air temperature $-60{ }^{\circ} \mathrm{C}$, duration $-540 \mathrm{~min}$, horizontal air flow velocity $-2.5 \mathrm{~m} / \mathrm{s}$, recuperation $-50 \%$. They were selected on the basis of experiments previously conducted in the Research Institute of Horticulture (Konopacka \& Mieszczakowska-Frąc 2014; Siucińska et al. 2016a), resulting in the obtaining of a product with water activity below 0.7 in order to minimize the risk of microbial spoilage. For each season and cultivar, the particular drying procedures were repeated twice.

\section{Quality analyses}

Both the raw material and the osmo-treated cherries were subjected to basic physicochemical analyses, such as dry matter content, titratable acidity, soluble solids, as well as chemical analyses including sugars, acids and phytonutrient profile and antioxidant capacity. As regards dried samples, the same analyses were carried out, with the exception of soluble solids, instead of which water activity was measured as an indicator of the final product stability.

\section{Description of the analytical methods}

Dry matter content was determined using the gravimetric method by drying to constant weight at $70^{\circ} \mathrm{C}$ under vacuum $\left(3 \times 10^{3} \mathrm{~Pa}\right)$ according to $\mathrm{PN} \mathrm{EN}$ 12145:2001. Titratable acidity (TA) was determined potentiometrically $\left(\mathrm{pH} 8.1\right.$ ) with $0.1 \mathrm{~mol} \cdot \mathrm{dm}^{-3} \mathrm{NaOH}$ using a Mettler Toledo Titrator. Results were expressed as grams of citric acid per 100 grams of sample $\left(\mathrm{g} \mathrm{CA}^{\circ} 100 \mathrm{~g}^{-1}\right)$. Soluble solids (SS) content was measured by the refractometric method (RE50 Refractometer, Mettler Toledo). The antioxidant activity (AA) was determined according to Re et al. (1999) and expressed as a 50\% reduction of $\mathrm{ABTS}^{\circ+}$ reagent solution absorbance, and recalculated to $\mathrm{mg}$ of Trolox equivalents per gram of dry matter. Measurements of water activity were performed at least 24 hours after drying, using HC2-AW-USB station probes connected to a PC running HW4-P-QUICKV3 software (Rotronic, B\&L, Poland) working with a measurement accuracy of \pm 0.008 Aw. HPLC equipment was used to determine sugars, acids and phenolic compounds and their quantities in samples. HPLC analysis of sugars was carried out according to a procedure described by Konopacka \& Mieszczakowska-Frąc (2014). 


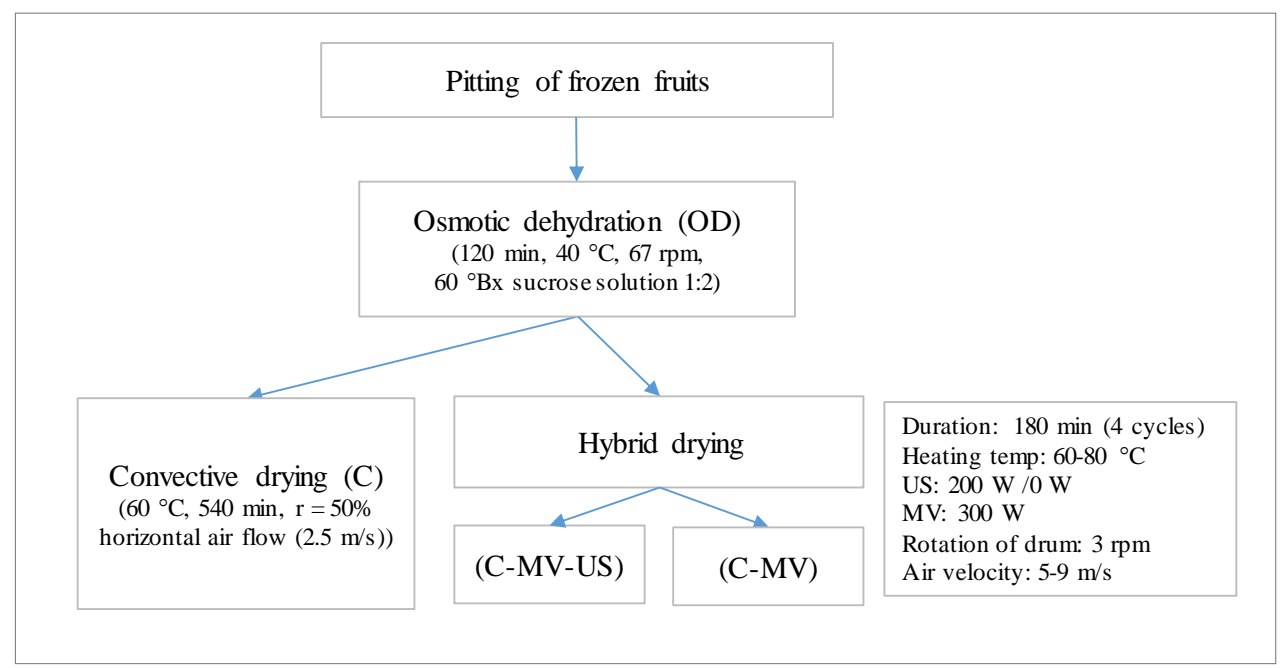

Fig. 1. Schematic diagram of the experiment

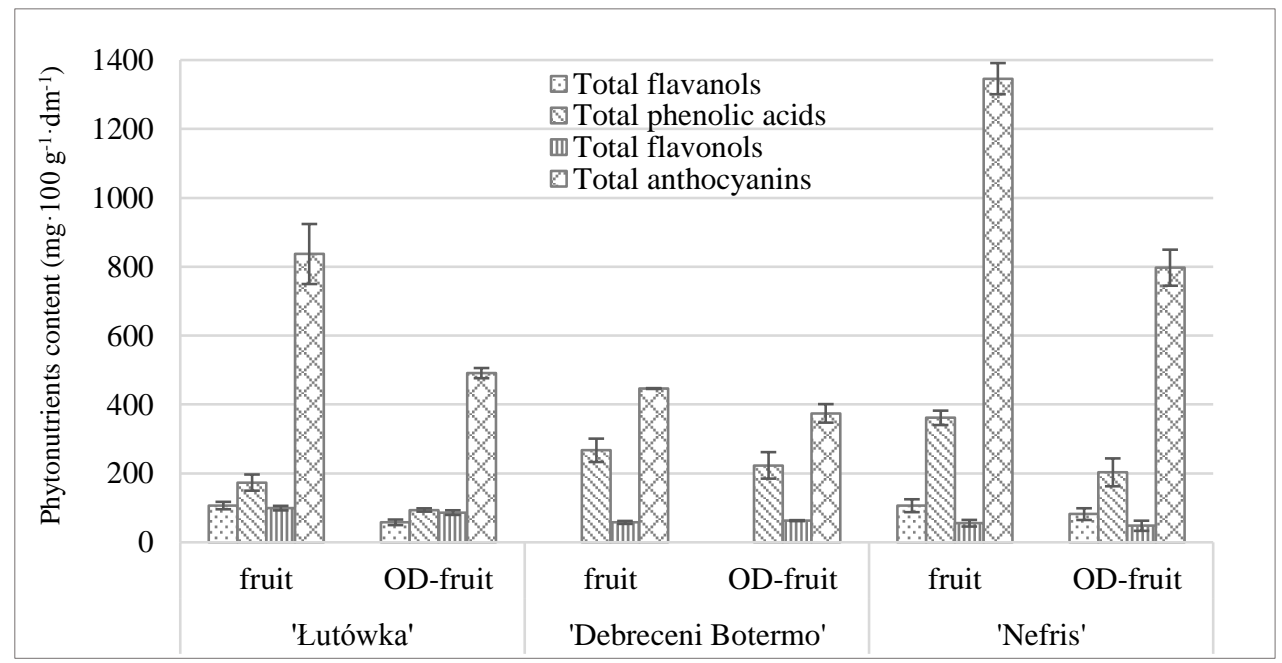

Fig. 2. Polyphenolic components profile of raw material and after osmotic dehydration depending on the cultivar. Means of the two seasons. Bar whiskers indicate \pm SD for four repetitions. Abbreviations: OD-fruit - osmotically dehydrated fruit
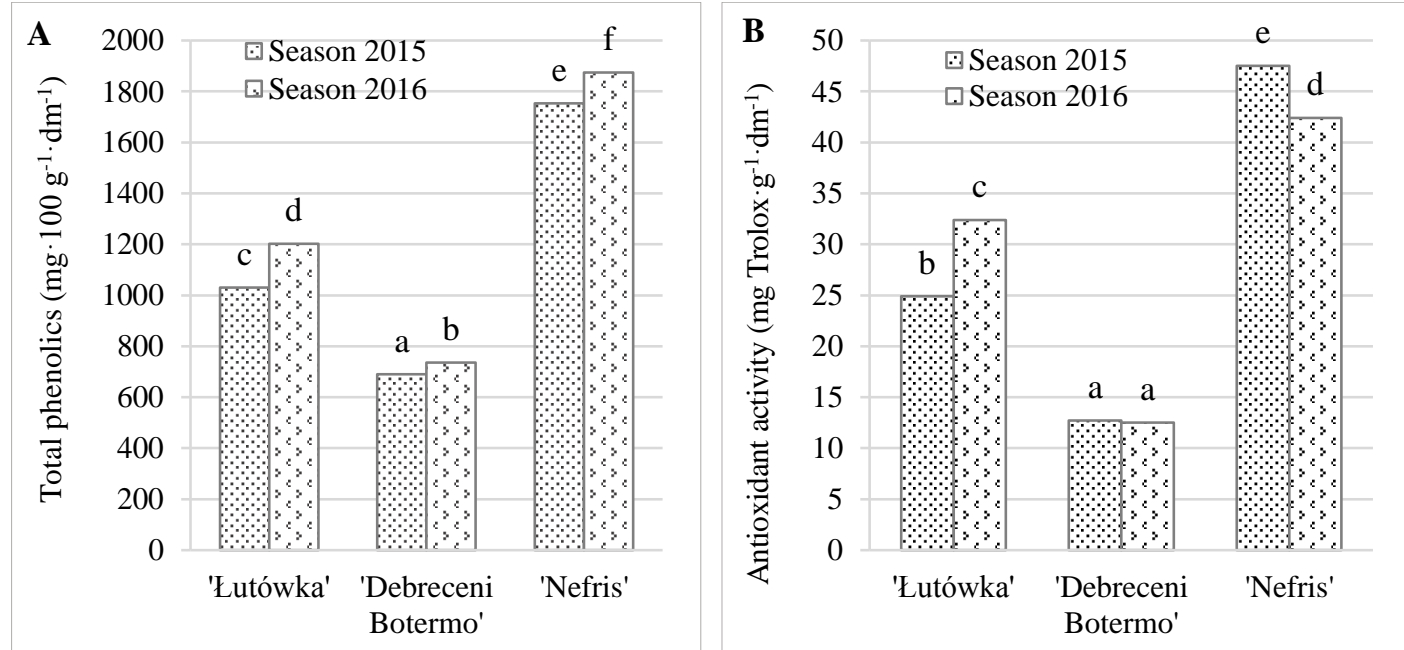

Fig. 3. Amount of total phenolic compounds (A) and antioxidant activity (B) in raw material in 2015 and 2016 harvesting seasons. Bars marked with the same letters do not differ significantly according to Duncan's multiple range test at $p=0.05$ 


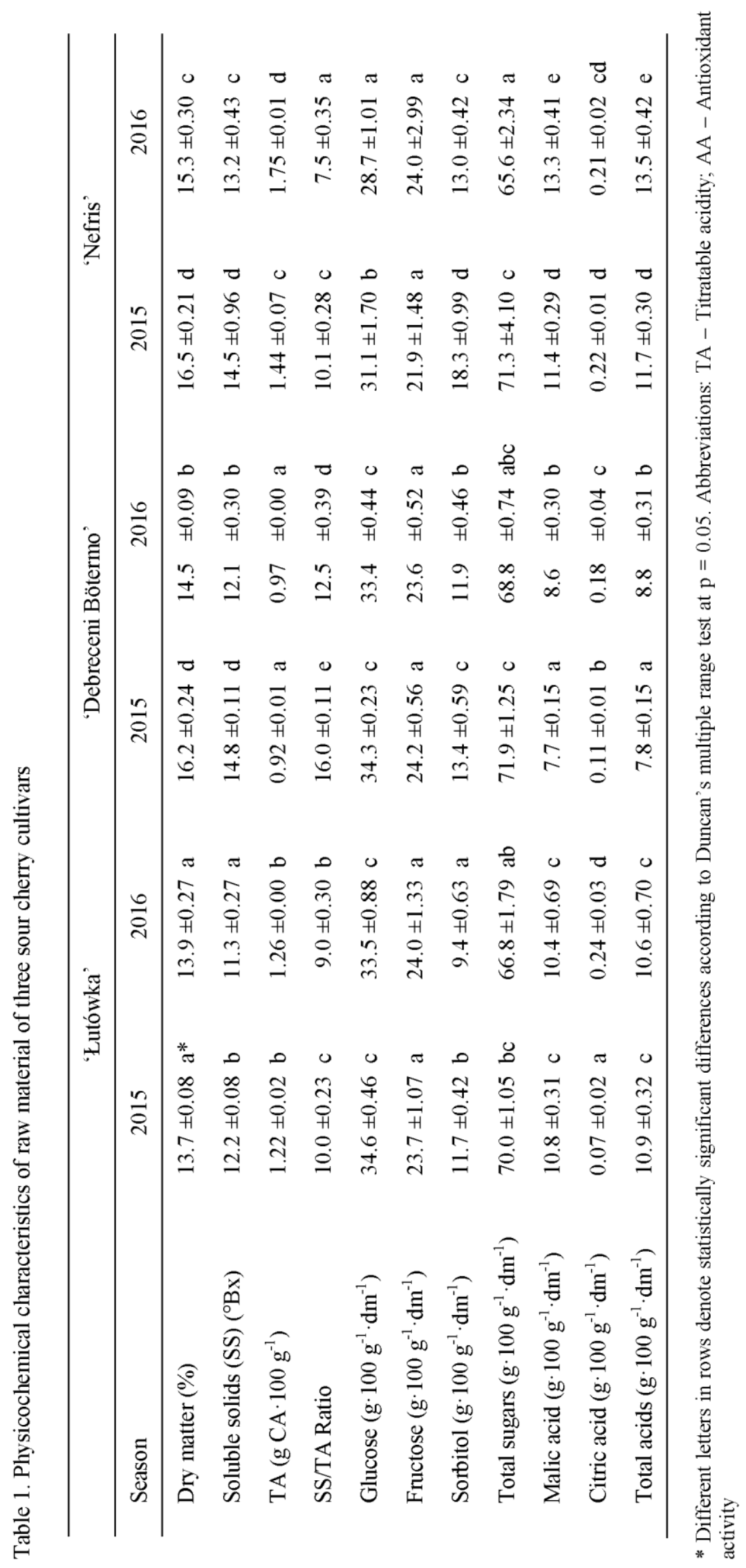


Ascorbic, malic and citric acid contents were determined according to the HPLC method detailed in the paper by Mieszczakowska-Frąc et al. (2015).

Qualitative HPLC analysis of phenolic compounds was performed according to the method described previously by Siucińska et al. (2016a).

\section{Statistical analysis}

The experimental results were statically analyzed using Statistica 12 software package (StatSoft, Inc., Tulsa, USA). To assess the impact of the variables on quality indicators, Analysis of Variance was used where cultivar $(\mathrm{C})$, season (S) and drying method (DM) were considered as sources of variation. Moreover, within the particular cultivars, One-Way ANOVA was carried out to check the effect of ultrasound assistance. Additionally, the statistical differences between means were determined using Duncan's multiple range test at a significance level of $\mathrm{p}=0.05$.

\section{RESULTS}

\section{Raw material characteristics}

The quality characteristics of the raw material are presented in Table 1. As anticipated, the chemical composition of each cultivar was different. Also, a strong influence of the growing season on almost every parameter of the sour cherry characteristics was identified. The only exception was the amount of fructose (Table 2). The mean soluble solids content calculated for 'Nefris' and 'Debreceni Bötermo' amounted to 13.9 and $13.5^{\circ}$ Brix, respectively. For 'Łutówka', the mean soluble solids value reached only $11.8^{\circ}$ Brix. With respect to fruit acidity, the measured values of titratable acidity were between 0.92 and $1.75 \mathrm{~g} \cdot 100 \mathrm{~g}^{-1}$ of fresh mass. In the case of this parameter, the lowest mean value was recorded for 'Debreceni Bötermo' (0.95 g·100 g-1). Regardless of the cultivar, the 2015 season brought about a higher concentration of SS and lower TA when compared to the 2016 harvesting season (Table 1). The calculated mean sugar/acid ratio (SS/TA ratio), considered to be an indicator of fruit sweetness, amounted to $8.80,9.50$ and 14.3 for 'Nefris', 'Lutówka' and 'Debreceni Bötermo', respectively. The details on the amount of glucose, sucrose and sorbitol, as well as malic and citric acids in the experimental fruit batches are given in Table 1.

The HPLC analyses of bioactive components confirmed the presence of 16 phenolic compounds belonging to 4 groups, namely flavanols, phenolic acids, flavonols and, the most important, anthocyanins. The quantitative differences between the groups for the investigated cultivars are presented in Fig. 2. The anthocyanin group was the most abundant and constituted $63-75 \%$ of the total polyphenols. The second largest group were phenolic acids, then flavanols (except for 'Debreceni Bötermo', which did not contain flavanols at all), while the last were flavonols. Although some differences were noticed between seasons in the quantity of particular polyphenolic compounds (Fig. 2), the total amount of polyphenols was strongly determined by the cultivar (Fig. 3A). The same tendency was found for antioxidant activity (Fig. 3B). The phenolic content and antioxidant activity were positively correlated $\left(R^{2}=0.941\right)$. The antiradical activity measured by the ABTS $^{*+}$ method for 'Nefris' was almost twice as high as that for ' $E u$ úwka', and almost four times higher than for the weakest 'Debreceni Bötermo' (Fig. 3B).

Table 2. Probability values of the $F$ statistic from ANOVA for the raw material characteristics

\begin{tabular}{|c|c|c|c|c|c|c|c|c|}
\hline \multirow{2}{*}{$\begin{array}{c}\text { Source } \\
\text { of variation }\end{array}$} & \multirow{2}{*}{$\begin{array}{l}\text { Dry matter } \\
(\%)\end{array}$} & \multirow{2}{*}{$\begin{array}{c}\text { Soluble } \\
\text { solids } \\
\left({ }^{\circ} \mathrm{Bx}\right)\end{array}$} & \multirow{2}{*}{$\begin{array}{l}\text { Titratable } \\
\text { acidity } \\
\left(\mathrm{g} \cdot 100 \mathrm{~g}^{-1}\right)\end{array}$} & \multicolumn{5}{|c|}{ Phenolic compounds $\left(\mathrm{mg} \cdot 100 \mathrm{~g}^{-1} \mathrm{dm}^{-1}\right)$} \\
\hline & & & & flavanols & $\begin{array}{l}\text { phenolic } \\
\text { acids }\end{array}$ & flavonols & anth. & total phen. \\
\hline Cultivar (CV) & $\mathbf{0}$ & 0.00 & 0.00 & 0.00 & 0.00 & 0.00 & 0.00 & 0.00 \\
\hline Season $(\mathrm{S})$ & 0 & 0.00 & 0.00 & 0.00 & $\mathbf{0 . 0 0}$ & 0.00 & 0.00 & 0.00 \\
\hline $\mathrm{CV} \times \mathrm{S}$ & $\mathbf{0 . 0 0}$ & $\mathbf{0 . 0 0}$ & 0.00 & 0.01 & 0.31 & $\mathbf{0 . 0 0}$ & $\mathbf{0 . 0 0}$ & $\mathbf{0 . 0 0}$ \\
\hline \multirow{2}{*}{$\begin{array}{l}\text { Source } \\
\text { of variation }\end{array}$} & \multicolumn{4}{|c|}{ Sugars $\left(g \cdot 100 \mathrm{~g}^{-1} \mathrm{dm}^{-1}\right)$} & \multicolumn{3}{|c|}{ Acids $\left(\mathrm{g} \cdot 100 \mathrm{~g}^{-1} \mathrm{dm}^{-1}\right)$} & AA \\
\hline & glucose & fructose & sorbitol & total sugars & malic acid & citric acid & total acids & $\left.\cdot 100 \mathrm{~g}^{-1} \mathrm{dm}^{-1}\right)$ \\
\hline Cultivar (CV) & 0.00 & 0.40 & 0.00 & 0.16 & 0.00 & 0.00 & $\mathbf{0 . 0 0}$ & 0.00 \\
\hline Season $(\mathrm{S})$ & 0.00 & 0.37 & 0.00 & 0.00 & 0.00 & 0.00 & 0.00 & 0.10 \\
\hline $\mathrm{CV} \times \mathrm{S}$ & 0.25 & 0.25 & 0.00 & 0.43 & 0.00 & 0.00 & 0.00 & 0.00 \\
\hline
\end{tabular}

Note: values in bold denote statistically significant effects $(\mathrm{p}=0.05)$. Abbreviations: anth. - anthocyanins; total phen. - total phenolics; AA - antioxidant activity 
Table 3. Effect of osmotic treatment on the physicochemical characteristics of sour cherry fruits in comparison with raw material (averages for two seasons)

\begin{tabular}{|c|c|c|c|c|c|c|}
\hline \multirow[b]{2}{*}{ Trait } & \multicolumn{2}{|c|}{ 'Łutówka' } & \multicolumn{2}{|c|}{ 'Debreceni Bötermo' } & \multicolumn{2}{|c|}{ 'Nefris' } \\
\hline & $\begin{array}{l}\text { Change } \\
\text { (unit) }\end{array}$ & OD-fruit & $\begin{array}{l}\text { Change } \\
\text { (unit) }\end{array}$ & OD-fruit & $\begin{array}{c}\text { Change } \\
\text { (unit) }\end{array}$ & OD-fruit \\
\hline Dry matter $(\%)$ & $8.6 \uparrow$ & $22.4 \pm 1.1^{*}$ & $5.8 \uparrow$ & $21.2 \pm 0.6^{*}$ & $8.7 \uparrow$ & $24.6 \pm 1.4^{*}$ \\
\hline Soluble solids (SS) $\left({ }^{\circ} \mathrm{Bx}\right)$ & $8.5 \uparrow$ & $20.3 \pm 1.0^{*}$ & $5.7 \uparrow$ & $19.2 \pm 0.4^{*}$ & $9.0 \uparrow$ & $22.8 \pm 2.1^{*}$ \\
\hline $\mathrm{TA}\left(\mathrm{g} \mathrm{CA} \cdot 100 \mathrm{~g}^{-1}\right)$ & $0.18 \downarrow$ & $1.06 \pm 0.04 *$ & $0.04 \downarrow$ & $0.91 \pm 0.03 *$ & $0.26 \downarrow$ & $1.33 \pm 0.17^{*}$ \\
\hline SS/TA Ratio & $9.7 \uparrow$ & $19.2 \pm 1.6^{*}$ & $6.9 \uparrow$ & $21.2 \pm 1.1^{*}$ & $8.8 \uparrow$ & $17.6 \pm 4.0^{*}$ \\
\hline Glucose $\left(\mathrm{g} \cdot 100 \mathrm{~g}^{-1} \cdot \mathrm{dm}^{-1}\right)$ & $2.6 \downarrow$ & $31.5 \pm 4.5$ & $0.6 \uparrow$ & $34.5 \pm 1.4$ & $6.7 \uparrow$ & $36.6 \pm 0.7 *$ \\
\hline Fructose $\left(\mathrm{g} \cdot 100 \mathrm{~g}^{-1} \cdot \mathrm{dm}^{-1}\right)$ & $2.2 \uparrow$ & $26.0 \pm 4.2$ & $4.3 \uparrow$ & $28.2 \pm 2.1^{*}$ & $7.7 \uparrow$ & $30.6 \pm 2.7^{*}$ \\
\hline Sorbitol $\left(\mathrm{g} \cdot 100 \mathrm{~g}^{-1} \cdot \mathrm{dm}^{-1}\right)$ & $4.0 \downarrow$ & $6.6 \pm 2.7^{*}$ & $4.8 \downarrow$ & $7.8 \pm 1.2 *$ & $8.0 \downarrow$ & $7.6 \pm 1.0 *$ \\
\hline Total sugars $\left(\mathrm{g} \cdot 100 \mathrm{~g}^{-1} \cdot \mathrm{dm}^{-1}\right)$ & $4.3 \downarrow$ & $64.1 \pm 10.8$ & $0.1 \uparrow$ & $70.5 \pm 3.0$ & $6.3 \downarrow$ & $74.8 \pm 2.3^{*}$ \\
\hline Malic acid $\left(\mathrm{g} \cdot 100 \mathrm{~g}^{-1} \cdot \mathrm{dm}^{-1}\right)$ & $5.4 \downarrow$ & $5.2 \pm 0.7 *$ & $3.1 \downarrow$ & $5.1 \pm 0.2 *$ & $6.5 \downarrow$ & $5.9 \pm 0.9 *$ \\
\hline Citric acid $\left(\mathrm{g} \cdot 100 \mathrm{~g}^{-1} \cdot \mathrm{dm}^{-1}\right)$ & $0.118 \downarrow$ & $0.040 \pm 0.007 *$ & $0.109 \downarrow$ & $0.041 \pm 0.002 *$ & $0.129 \downarrow$ & $0.089 \pm 0.056^{*}$ \\
\hline Total acids $\left(\mathrm{g} \cdot 100 \mathrm{~g}^{-1} \cdot \mathrm{dm}^{-1}\right)$ & $5.5 \downarrow$ & $5.3 \pm 0.7 *$ & $3.2 \downarrow$ & $5.1 \pm 0.2 *$ & $6.6 \downarrow$ & $6.0 \pm 0.9 *$ \\
\hline Total phenolics $\left(\mathrm{g} \cdot 100 \mathrm{~g}^{-1} \cdot \mathrm{dm}^{-1}\right)$ & $474 \downarrow$ & $643 \pm 26.9 *$ & $115 \downarrow$ & $598 \pm 50.0^{*}$ & $732 \downarrow$ & $1082 \pm 95.3 *$ \\
\hline AA $\left(\mathrm{mg}\right.$ Trolox $\left.\cdot 100 \mathrm{~g}^{-1} \mathrm{dm}^{-1}\right)$ & $10.4 \downarrow$ & $18.3 \pm 1.3^{*}$ & $1.3 \downarrow$ & $11.3 \pm 1.0 *$ & $14.8 \downarrow$ & $30.1 \pm 1.4 *$ \\
\hline
\end{tabular}

Change is the value of decrease $(\downarrow)$ or increase $(\uparrow)$ in a particular trait after osmotic dehydration expressed in the unit of measure of that trait *Asterisks denote statistical significance between raw material and dehydrated fruits of cultivars tested using Duncan's multiple range test at $\mathrm{p}=0.05$. Abbreviations: OD - Osmotically dehydrated; SS - soluble solids; TA - Titratable acidity; AA - Antioxidant activity

\section{Characteristics of osmotically pretreated sour cherry fruits}

The changes in the quality characteristics of sour cherry fruit caused by the osmotic pretreatment are illustrated in Table 3. In the column 'change', the value of decrease $(\downarrow)$ or increase $(\uparrow)$ in a particular trait after osmotic dehydration is shown compared to raw material and expressed in the unit of measure of that trait.

Under the applied conditions of osmotic treatment (60 ${ }^{\circ}$ Brix sucrose solution, $40{ }^{\circ} \mathrm{C}, 120 \mathrm{~min}$.), the dry matter content in fruit tissue increased by an average of 63, 38 and 55\% in 'Łutówka', 'Debreceni Bötermo' and 'Nefris', respectively. It can easily be seen that the mass transfer for 'Debreceni' was less effective, which seems to be a cultivar-dependent effect, and can probably be explained by the greater thickness of the skin or covering waxy layer than in the other cultivars. Along with the increase in dry matter, being the consequence of the rise in soluble solids, a slight decrease in titratable acidity was observed, which is connected with the leakage of organic acids to osmotic solutions. These changes, in turn, altered the SS/TA ratio, which is helpful in forecasting the sweetness of the final product. Due to the applied pretreatment, the SS/TA ratio increased twofold for ' $Ł u$ úwka' and 'Nefris', and 1.5 times for 'Debreceni Bötermo' (Table 3). The diffusion processes brought about other changes which were connected with the leakage of water soluble compounds of cell sap, such as sorbitol (the observed reduction varied between 37$52 \%$ ), or other low mass constituents, including biologically active substances.

As expected, the pretreatment stage led to a substantial reduction in the sour cherry phytonutrients (Fig. 2). The most severe losses of phenolics $(42 \%)$ were observed in 'Łutówka', lower for ' $\mathrm{Ne}-$ fris' (40\%) and the lowest in 'Debreceni' (16\%). In spite of such differences, the amount of these compounds in 'Debreceni' was still lower than in 'Nefris', which retained the highest amount. The latter cultivar was also able to maintain the highest antioxidant activity (Table 3 ).

\section{Effect of the drying method on the properties of the final product}

In the case of dried products, the cultivar had a significant influence on all parameters, while the growing season affected almost all of them, the exception being flavanols. The drying method, in turn, had an 
effect on 11 out of the 16 values measured (Table 4). However, due to the fact that the cumulative effect of drying method $\times$ season on the phenolic compounds (except phenolic acids, which are marked in bold) and the profiles of sugars and acids did not show statistical significance, it was decided to interpret the results using average values for the two seasons.

The effect of the drying procedures applied to the fruits of the investigated sour cherry cultivars is presented in Table 5. Unfortunately, the convective drying conditions turned out to be not strong enough to ensure microbial stability for 'Debreceni Bötermo' (water activity above 0.7 ), whilst for 'Lutówka' they lasted slightly too long and led to over drying (water activity 0.5). Again, like during osmotic dehydration, the 'Debreceni Bötermo' turned out to be more resistant to water loss than 'Łutówka' and 'Nefris'.
Despite the fact that before drying the difference in dry matter content between 'Debreceni Bötermo' and 'Łutówka' was only 1.2 units (21.2 and 22.4\% of dry matter respectively for 'Debreceni' and 'Łutówka'; Table 3), after drying it rose to 18.8 units (69.4 and $88.2 \%$, respectively; Table 5), which confirms poor suitability of this cultivar for convective drying. In the case of 'Łutówka', the classic convective drying on trays turned out to give a product with the lowest amount of remaining water.

The discrepancies between the cultivars substantially diminished when the hybrid drying methods were applied. Using the combination of convective drying with microwave energy (C-MV) did not only lead to the shortening of drying time to 3 hours, but also passed over the dehydration barrier observed for 'Debreceni Bötermo' during classic convective drying.

Table 4. Probability values of the $F$ statistic from ANOVA for dried product characteristics

\begin{tabular}{|c|c|c|c|c|c|c|c|c|}
\hline \multirow{2}{*}{ Source of variation } & \multirow{2}{*}{$\begin{array}{c}\text { Dry mat- } \\
\text { ter }(\%)\end{array}$} & \multirow{2}{*}{$\begin{array}{c}\text { Titratable } \\
\text { acidity } \\
\left(\mathrm{g} \cdot 100 \mathrm{~g}^{-1}\right)\end{array}$} & \multirow{2}{*}{$\begin{array}{l}\text { Water } \\
\text { activity }\end{array}$} & \multicolumn{5}{|c|}{ Phenolic compounds $\left(\mathrm{mg} \cdot 100 \mathrm{~g}^{-1} \cdot \mathrm{dm}^{-1}\right)$} \\
\hline & & & & flavanols & $\begin{array}{c}\text { phenolic } \\
\text { acids }\end{array}$ & flavonols & anth. & total phen. \\
\hline Cultivar (CV) & 0.00 & 0.00 & 0.00 & 0.00 & 0.00 & 0.00 & 0.00 & 0.00 \\
\hline Drying method $(\mathrm{M})^{*}$ & $\mathbf{0 . 0 0}$ & 0.00 & 0.00 & 0.02 & $\mathbf{0 . 0 0}$ & 0.56 & 0.00 & 0.00 \\
\hline Season $(\mathrm{S})$ & 0.00 & 0.00 & 0.00 & 0.51 & 0.00 & 0.00 & 0.00 & 0.00 \\
\hline $\mathrm{CV} \times \mathrm{M}$ & 0.00 & 0.00 & 0.00 & 0.04 & 0.00 & 0.04 & 0.00 & 0.00 \\
\hline $\mathrm{CV} \times \mathrm{S}$ & $\mathbf{0 . 0 0}$ & 0.00 & 0.00 & 0.00 & 0.00 & 0.00 & 0.00 & 0.00 \\
\hline $\mathrm{M} \times \mathrm{S}$ & 0.01 & 0.00 & 0.00 & 0.18 & 0.02 & 0.68 & 0.71 & 0.36 \\
\hline $\mathrm{CV} \times \mathrm{M} \times \mathrm{S}$ & 0.37 & 0.09 & 0.00 & 0.69 & 0.09 & 0.96 & 0.51 & 0.53 \\
\hline \multirow{2}{*}{ Source of variation } & \multicolumn{4}{|c|}{ Sugars $\left(\mathrm{g} \cdot 100 \mathrm{~g}^{-1} \cdot \mathrm{dm}^{-1}\right)$} & \multicolumn{3}{|c|}{ Acids $\left(\mathrm{g} \cdot 100 \mathrm{~g}^{-1} \cdot \mathrm{dm}^{-1}\right)$} & \\
\hline & glucose & fructose & sorbitol & total sugars & malic acid & citric acid & total acids & $\left.\cdot \mathrm{g}^{-1} \cdot \mathrm{dm}^{-1}\right)$ \\
\hline Cultivar (CV) & 0.00 & 0.00 & 0.00 & 0.00 & 0.00 & 0.00 & 0.00 & 0.00 \\
\hline Drying method $(\mathrm{M})^{*}$ & 0.16 & 0.00 & 0.76 & 0.00 & 0.11 & 0.01 & 0.11 & 0.00 \\
\hline Season $(S)$ & 0.00 & 0.00 & 0.00 & 0.00 & 0.01 & 0.00 & 0.00 & 0.00 \\
\hline $\mathrm{CV} \times \mathrm{M}$ & 0.24 & 0.08 & 0.60 & 0.01 & 0.01 & 0.00 & 0.01 & 0.00 \\
\hline $\mathrm{CV} \times \mathrm{S}$ & 0.11 & 0.18 & 0.52 & 0.02 & 0.00 & 0.00 & 0.00 & 0.00 \\
\hline $\mathrm{M} \times \mathrm{S}$ & 0.24 & 0.97 & 0.31 & 0.28 & 0.07 & 0.35 & 0.09 & 0.03 \\
\hline $\mathrm{CV} \times \mathrm{M} \times \mathrm{S}$ & 0.24 & 0.00 & 0.08 & $\mathbf{0 . 0 0}$ & 0.16 & 0.01 & 0.20 & 0.00 \\
\hline
\end{tabular}

*Drying method: C; C-MV-US; C-MV.

Note: values in bold denote statistically significant effects $(p=0.05)$ 
Table 5. Effect of drying method on the physicochemical characteristics of dried sour cherries fruits of three cultivars. Means of two seasons

\begin{tabular}{|c|c|c|c|c|c|c|c|c|c|}
\hline Cultivar & $\begin{array}{l}\text { Drying } \\
\text { method }\end{array}$ & \multicolumn{2}{|c|}{ Dry matter (\%) } & \multicolumn{2}{|c|}{$\begin{array}{l}\text { Titratable acidity } \\
\left(\mathrm{g} \cdot 100 \mathrm{~g}^{-1}\right)\end{array}$} & \multicolumn{2}{|c|}{ Water activity } & \multicolumn{2}{|c|}{$\begin{array}{c}\text { Total acids } \\
\left(\mathrm{g} \cdot 100 \mathrm{~g}^{-1} \cdot \mathrm{dm}^{-1}\right)\end{array}$} \\
\hline \multirow{3}{*}{ 'Łutówka' } & $\mathrm{C}$ & $88.2 \pm 3.20$ & $b^{*}$ & $4.07 \pm 0.22$ & $\mathrm{a}$ & $0.517 \pm 0.064$ & $\mathrm{a}$ & $5.02 \pm 0.61$ & $\mathrm{a}$ \\
\hline & C-MV-US & $85.9 \pm 1.12$ & $\mathrm{a}$ & $4.15 \pm 0.29$ & $\mathrm{a}$ & $0.568 \pm 0.011$ & $\mathrm{~b}$ & $5.31 \pm 0.64$ & $\mathrm{a}$ \\
\hline & C-MV & $83.7 \pm 1.51$ & $\mathrm{a}$ & $3.89 \pm 0.27$ & $\mathrm{a}$ & $0.607 \pm 0.014$ & $\mathrm{c}$ & $4.80 \pm 0.73$ & $\mathrm{a}$ \\
\hline \multirow{3}{*}{$\begin{array}{l}\text { 'Debreceni } \\
\text { Bötermo' }\end{array}$} & $\mathrm{C}$ & $69.4 \pm 4.77$ & $\mathrm{a}$ & $3.02 \pm 0.28$ & $\mathrm{a}$ & $0.776 \pm 0.053$ & $\mathrm{c}$ & $5.01 \pm 0.12$ & $\mathrm{a}$ \\
\hline & C-MV-US & $81.0 \pm 1.64$ & $\mathrm{~b}$ & $3.57 \pm 0.26$ & $\mathrm{~b}$ & $0.666 \pm 0.023$ & $\mathrm{a}$ & $4.96 \pm 0.36$ & $\mathrm{a}$ \\
\hline & C-MV & $78.9 \pm 3.37$ & $\mathrm{~b}$ & $3.40 \pm 0.16$ & $\mathrm{~b}$ & $0.695 \pm 0.040$ & $\mathrm{~b}$ & $5.00 \pm 0.19$ & $\mathrm{a}$ \\
\hline \multirow{3}{*}{ 'Nefris' } & $\mathrm{C}$ & $82.1 \pm 2.35$ & $\mathrm{a}$ & $4.42 \pm 0.95$ & $\mathrm{a}$ & $0.639 \pm 0.042$ & $\mathrm{~b}$ & $5.79 \pm 1.05$ & $\mathrm{a}$ \\
\hline & C-MV-US & $83.8 \pm 0.48$ & $\mathrm{a}$ & $4.49 \pm 0.73$ & $\mathrm{a}$ & $0.620 \pm 0.010$ & $\mathrm{a}$ & $5.73 \pm 0.75$ & $\mathrm{a}$ \\
\hline & C-MV & $82.8 \pm 1.41$ & $\mathrm{a}$ & $4.52 \pm 0.78$ & $\mathrm{a}$ & $0.632 \pm 0.023$ & $\mathrm{ab}$ & $5.76 \pm 0.72$ & $\mathrm{a}$ \\
\hline \multirow{2}{*}{ Cultivar } & Drying & \multicolumn{8}{|c|}{ Sugars $\left(\mathrm{g} \cdot 100 \mathrm{~g}^{-1} \cdot \mathrm{dm}^{-1}\right)$} \\
\hline & method & \multicolumn{2}{|l|}{ glucose } & \multicolumn{2}{|l|}{ fructose } & \multicolumn{2}{|l|}{ sorbitol } & \multicolumn{2}{|c|}{ total sugars } \\
\hline \multirow{3}{*}{ 'Łutówka' } & $\mathrm{C}$ & $36.5 \pm 1.42$ & $\mathrm{a}$ & $32.0 \pm 1.48$ & $\mathrm{a}$ & $4.95 \pm 0.85$ & $\mathrm{a}$ & $73.5 \pm 2.09$ & $\mathrm{~b}$ \\
\hline & C-MV-US & $35.7 \pm 1.36$ & $\mathrm{a}$ & $30.5 \pm 1.95$ & $\mathrm{a}$ & $4.50 \pm 0.47$ & $\mathrm{a}$ & $70.8 \pm 2.12$ & $\mathrm{a}$ \\
\hline & C-MV & $36.4 \pm 1.41$ & $\mathrm{a}$ & $31.6 \pm 1.78$ & $\mathrm{a}$ & $4.75 \pm 0.94$ & $\mathrm{a}$ & $72.8 \pm 1.82$ & $\mathrm{ab}$ \\
\hline \multirow{3}{*}{$\begin{array}{l}\text { 'Debreceni } \\
\text { Bötermo' }\end{array}$} & $\mathrm{C}$ & $35.9 \pm 0.84$ & $\mathrm{~b}$ & $29.6 \pm 0.83$ & a & $6.78 \pm 0.86$ & $\mathrm{a}$ & $72.3 \pm 0.93$ & $\mathrm{a}$ \\
\hline & C-MV-US & $35.3 \pm 0.82$ & $\mathrm{ab}$ & $28.3 \pm 0.71$ & $\mathrm{a}$ & $6.75 \pm 1.34$ & $\mathrm{a}$ & $70.4 \pm 1.51$ & $\mathrm{a}$ \\
\hline & C-MV & $34.9 \pm 0.93$ & $\mathrm{a}$ & $28.6 \pm 2.24$ & $\mathrm{a}$ & $6.85 \pm 0.91$ & $\mathrm{a}$ & $70.3 \pm 2.62$ & $\mathrm{a}$ \\
\hline \multirow{3}{*}{ 'Nefris' } & $\mathrm{C}$ & $34.7 \pm 0.87$ & a & $30.7 \pm 1.78$ & $\mathrm{a}$ & $7.10 \pm 0.97$ & $\mathrm{a}$ & $72.6 \pm 2.57$ & $\mathrm{a}$ \\
\hline & C-MV-US & $34.7 \pm 1.35$ & $\mathrm{a}$ & $30.5 \pm 2.30$ & $\mathrm{a}$ & $7.34 \pm 1.32$ & $\mathrm{a}$ & $72.5 \pm 2.59$ & $\mathrm{a}$ \\
\hline & C-MV & $34.9 \pm 0.91$ & $\mathrm{a}$ & $31.7 \pm 1.01$ & $\mathrm{a}$ & $7.36 \pm 0.96$ & $\mathrm{a}$ & $73.9 \pm 1.28$ & $\mathrm{a}$ \\
\hline
\end{tabular}

* Different letters in columns, for each cultivar separately, denote statistically significant differences according to Duncan's multiple range test $\mathrm{p}=0.05$. Abbreviations: $\mathrm{C}-$ convective drying; C-MV-US - convective-microwaveultrasound drying;. C-MV - convective-microwave drying

In the second hybrid method tested (C-MVUS), where ultrasound energy was also used to enhance water removal from the fruit, the additional source of energy slightly improved mass transfer, making the dehydration process more effective than without US. Regardless of the cultivar, the samples dried with US assistance were characterized by lower water activity. The details on the influence of drying methods on the chemical composition of fruit of the investigated cultivars are given in Table 5 . With the exception of water activity, no significant differences between the two hybrid methods were observed in the investigated physicochemical parameters. The same applied to bioactives (Table 6), except for flavanols and flavonols in 'Lutówka' (higher retention for hybrid method with US).

With regard to antioxidant activity, the 'Nefris' and 'Debreceni Bötermo' fruits dried with the hybrid methods were better protected against losses of antioxidant potential than the convectively dried fruits. Comparing the two hybrid methods, although the difference was not statistically significant, the antioxidant activity for 'Łutówka' and 'Debreceni Bötermo' was higher in C-MV-US-dried samples, whilst for 'Nefris' the C-MV sample gave the higher result. Irrespective of the drying method, 'Nefris' was the cultivar with definitely the highest antioxidant potential (about $1.7 \times$ higher than in ' $Ł u t o ́ w k a '$ and $2.6 \times$ higher than in DB) (Table 6 ).

The antioxidant activity of a product depends on the polyphenolic content. Table 4 shows the effect of drying method and cultivar as well as season on the total polyphenolic content and other characteristics of the dried product. As was proved, the cultivar effect was dominating, while the drying method influenced the bioactive components to a lesser extent. 


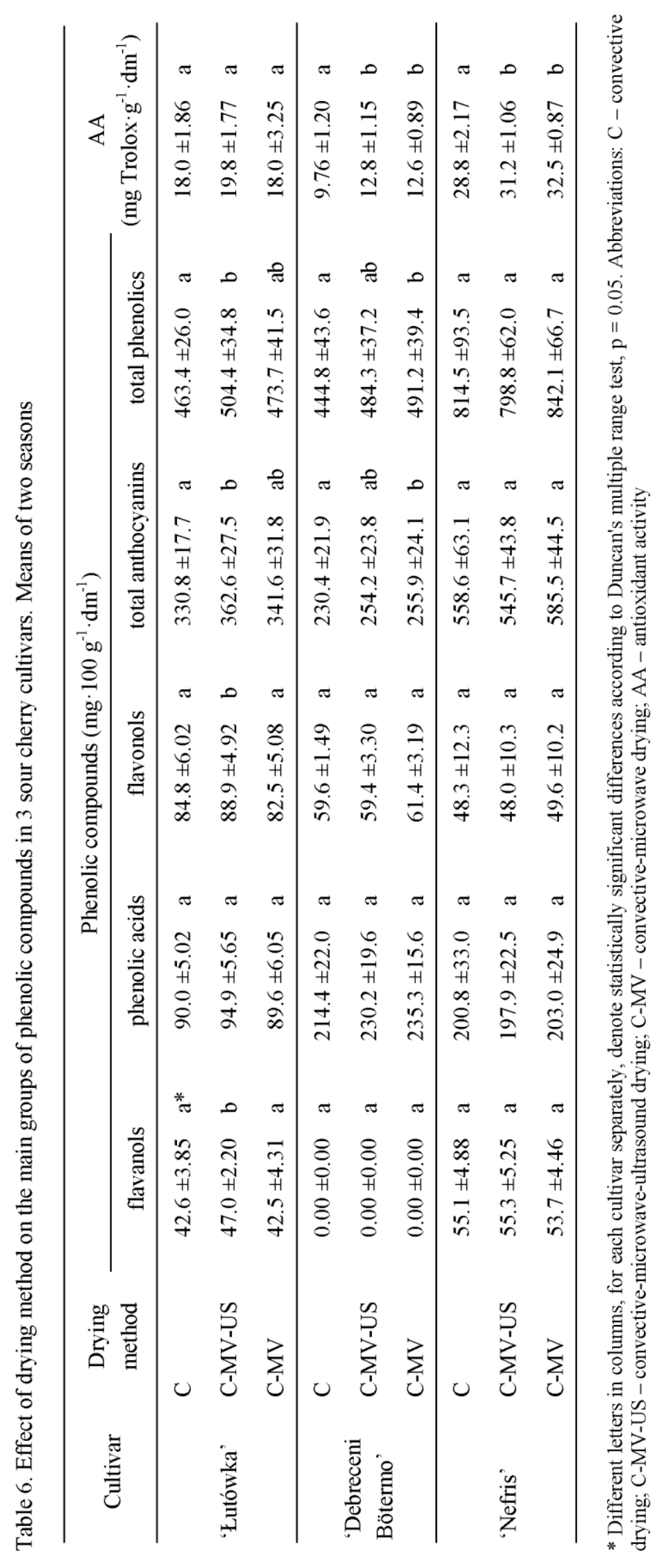


The details on the retention pattern of a particular polyphenolic group with regard to the drying method are presented in Table 6. The anthocyanins group is the most abundant phytonutrient group in sour cherries and it has the biggest impact on the final bioactivity. The correlation coefficient between the antioxidant activity and the anthocyanin content remained very high and reached 0.958, while in relation to total polyphenols it was 0.849 .

Regarding the effect of ultrasound assistance applied in the hybrid drying, US turned out to have a slight (cultivar-dependent) effect on the retention of polyphenols.

\section{DISCUSSION}

It is widely known that drying conditions influence the quality of dried material. As regards sour cherry, Wojdyło et al. (2014b) had proved that bioactivity of this species was better protected in mild drying conditions, namely short drying time, low temperature and limited material contact with oxygen in the drying air. Therefore, combined methods, like vacuum-microwave drying or hybrid drying, usually give better results than classic convective drying. Their study revealed that properly chosen microwave power contributed to higher amounts of total phenolics and anthocyanins, attractive color and high antioxidant activity. Our results do not exactly comply with these conclusions. In our experiment, the hybrid method admittedly allowed the drying time to become shorter; however, it did not cause the expected better preservation of phenolic compounds. Irrespective of the drying method applied, the level of bioactives was similar in all the dried samples, despite the significant shortening of the hybrid drying time.

The results are especially surprising taking into account that ultrasonic waves, widely considered to be a very promising means of providing assistance in the drying of plant material, were used among the techniques applied. There can be several reasons for such untypical outcomes. The usefulness of ultrasound depends on individual optimization and precise dosage (Siucińska \& Konopacka 2014; Musielak et al. 2016; Rajewska \& Mierzwa 2017). First of all, the choice of raw material should be carefully considered, then the osmotic agent and the construction of drying equipment, and finally the process parameters such as ultrasound power and method of application, air temperature and velocity (Cárcel et al. 2007), with the quantity of sample subjected to sonication being also important.

Direct sonication of a small amount of sample is definitely more effective than an air-borne system, especially when the sample is much bigger. In the latter system, the transfer of acoustic waves to the sample is limited because the air greatly attenuates and absorbs the acoustic energy (Fan et al. 2017). In our experiment, there was $1 \mathrm{~kg}$ of dehydrated fruits subjected to drying. The majority of experiments had been conducted only on a small scale, taking 10 to 50 grams of material. In those cases, applying ultrasound was beneficial because of accurate and cumulative interaction of ultrasound and the material being dried. When it comes to drying on a larger scale, the results are not so satisfactory, like in our case. Moreover, it is highly probable that in air-borne systems the power density of ultrasonic waves is not appropriate. Konopacka et al. (2015b) have proposed a hypothesis that US power above $0.5-1 \mathrm{~kW}$ per $1 \mathrm{~kg}$ of dried material should be sufficient for accelerating the drying process.

Another probable reason why, despite the significantly shorter drying time, needed to obtain product stability, the hybrid drying methods did not produce the expected effect of higher retention of bioactive components could be the shape of the drying chamber. Sour cherry fruits dried in a drum are likely to be more exposed to the drying air and oxygen than those dried on trays. Moreover, during the constant movement of material the fruit surface is subjected to abrasion, which exposes deeper layers of cells to unfavorable deterioration of oxygen-sensitive compounds (Braga et al. 2017). Taking the above into consideration, future experiments with hybrid drying in a drum chamber should focus on incorporating a coating film capable of preventing losses of bioactive components.

Despite the absence of a positive effect of the hybrid drying method on the antioxidant properties of the dried sour cherry snack, the effect of reducing the drying time to a third still remains a serious 
argument in favor of implementing such a drying system into practice.

As already mentioned in the Introduction, apart from drying methods, proper cultivar selection also has to be mentioned as a promising tool for influencing the nutritional value of processed sour cherry products (Konopacka \& MieszczakowskaFrąc 2014). From among ten cultivars of sour cherry, the cited authors indicated the cultivar 'Nefris' as the most valuable for the purpose of drying, mainly due to the high initial anthocyanin and polyphenolic contents. Our results confirmed why 'Nefris' and 'Łutówka' are commonly recognized as industrial cultivars suitable for processing, on the basis of SS/TA ratio, which was significantly lower for these two cultivars, and they are more sour, while 'Debreceni Bötermo' is regarded rather as a table cultivar, suitable for direct consumption. Wojdyło et al. (2014a), investigating polyphenolic content, antioxidant properties and other nutritional components in 33 sour cherry cultivars, had also confirmed that bioactive properties of this species were highly dependent on the cultivar. As regards the aspect of forecasting the nutritional value of the processed sour cherry fruit, the region of origin and harvest period might also have an influence on plant growth and metabolite concentration (Khoo et al. 2011). In Denmark, 'Nefris' was also in the group of cultivars with a high total phenolic and anthocyanin content, whilst 'Lutówka' was in the middle. Further, Khoo et al. (2011) had proved that 'Nefris', as a cultivar with higher levels of the above-mentioned compounds, showed greater antioxidant capacity and inhibition activity against cancer cell proliferation. Summarizing, irrespective of the locations, researchers more often indicate 'Nefris' as the most promising cultivar in terms of obtaining nutritionally valuable products. This consistency remains in agreement with our results.

\section{CONCLUSIONS}

Using a combination of convective drying with microwave energy (C-MV) reduced the drying time to a third, compared to convective drying. Hybrid drying eliminated the problems associated with the dehydration barrier observed in 'Debreceni
Bötermo' during convective drying, when applied individually.

Ultrasound used as the additional source of energy in the hybrid drying technique improved the water evaporation, but without significantly affecting the levels of phenolic compounds.

The effect of the cultivar is crucial to the drying process and the quality of the final product. Under the same processing conditions, 'Nefris' turned out to be the most promising cultivar for producing ready-to-eat fruit snacks of high nutritional value. This cultivar showed the highest antioxidant potential and, irrespective of the processing method, the amount of phenolic compounds remained at the highest level when compared to other cultivars.

The results of this investigation indicate that the use of ultrasound can modify the quality of the final product, while the choice of cultivar not only influences product attractiveness but also has a major impact on its pro-health properties.

\section{REFERENCES}

Bell P.G., Gaze D.C., Davison G.W., George T.W., Scotter M.J., Howatson G. 2014. Montmorency tart cherry (Prunus cerasus L.) concentrate lowers uric acid, independent of plasma cyanidin-3-O-glucosiderutinoside. Journal of Functional Foods 11: 8290. DOI: 10.1016/j.jff.2014.09.004.

Braga A.R.C., Murador D.C, de Souza Mesquita L.M., de Rosso V.V. 2017. Bioavailability of anthocyanins: Gaps in knowledge, challenges and future research. Journal of Food Composition and Analysis 68: 31-40. DOI: 10.1016/j.jfca.2017.07.031.

Calín-Sánchez Á., Kharaghani A., Lech K., Figiel A., Carbonell-Barrachina Á.A., Tsotsas E. 2015. Drying kinetics and microstructural and sensory properties of black chokeberry (Aronia melanocarpa) as affected by drying method. Food and Bioprocess Technology 8(1): 63-74. DOI: 10.1007/s11947014-1383-x.

Cárcel J.A., Garciá-Pérez J.V., Riera E., Mulet A. 2007. Influence of high-intensity ultrasound on drying kinetics of persimmon. Drying Technology 25: 185193. DOI: $10.1080 / 07373930601161070$.

Damar İ., Ekşi A. 2012. Antioxidant capacity and anthocyanin profile of sour cherry (Prunus cerasus L.) juice. Food Chemistry 135: 2910-2914. DOI: 10.1016/j.foodchem.2012.07.032. 
Fan K., Zhang M., Mujumdar A.S. 2017. Application of airborne ultrasound in the convective drying of fruits and vegetables: a review. Ultrasonics - Sonochemistry 39: 47-57. DOI: 10.1016/j.ultsonch.2017.04.001.

Figiel A., Michalska A. 2017. Overall quality of fruits and vegetables products affected by the drying processes with the assistance of vacuum-microwaves. International Journal of Molecular Sciences 18(1; 71), 18 p. DOI: 10.3390/ijms 18010071.

Horuz E., Bozkurt H., Karataş H., Maskan M. 2017. Effects of hybrid (microwave-convectional) and convectional drying on drying kinetics, total phenolics, antioxidant capacity, vitamin $\mathrm{C}$, color and rehydration capacity of sour cherries. Food Chemistry 230: 295-305. DOI: 10.1016/j.foodchem.2017.03.046.

Khoo G.M., Clausen M.R., Pedersen B.H., Larsen E. 2011. Bioactivity and total phenolic content of 34 sour cherry cultivars. Journal of Food Composition and Analysis 24: 772-776. DOI: 10.1016/j.jfca.2011.03.004.

Konopacka D., Cybulska J., Zdunek A., Dyki B., Machlańska A., Celejewska K. 2017. The combined effect of ultrasound and enzymatic treatment on the nanostructure, carotenoid retention and sensory properties of ready-to-eat carrot chips. LWT - Food Science and Technology 85: 427-433. DOI: 10.1016/j.lwt.2016.11.085.

Konopacka D., Jesionkowska K., Klewicki R., Bonazzi C. 2009. The effect of different osmotic agents on the sensory perception of osmo-treated dried fruit. Journal of Horticultural Science and Biotechnology 84(6): 80-84; ISAFRUIT (Special issue). DOI: 10.1080/14620316.2009.11512600.

Konopacka D., Kowalski S.J. 2013. Application of ultrasound to enhance drying processes of biological materials especially susceptible to thermal exposure. Proceedings of XIII Polish Drying Symposium. 5-6 September, Poland, CD-ROM: 262, 3 p.

Konopacka D., Parosa R., Piecko J., Połubok A., Siucińska K. 2015b. Ultrasound \& microwave hybrid drying device for colored fruit preservation - product quality and energy efficiency. Proceedings of the $8^{\text {th }}$ Asia-Pacific Drying Conference (ADC 2015). 10-12 August, Malaysia, pp. 252-258.

Konopacka D., Płocharski W., Siucińska K., Kowalski S.J., Mierzwa D. 2015a. Ultrasound application as a useful technique in the enhancement of fruit and vegetable drying. Przemysł Fermentacyjny i OwocowoWarzywny 59(9): 27-31. DOI: 10.15199/64.2015.9.3. [in Polish with English abstract]
Konopacka D., Mieszczakowska-Frąc M. 2014. The quantitative and qualitative changes of sugars in sour cherry fruit subjected to osmo-convective drying. Zeszyty Problemowe Postępów Nauk Rolniczych 578: 61-70. [in Polish with English abstract]

Konopacka D., Siucińska K., Grześkowiak P., Kowalczyk K., Ziętek P., Żytkiewicz J., Parosa R. 2017. Suszarka. Patent PL 227427 B1.

Kowalski S.J., Pawłowski A. 2015. Intensification of apple drying due to ultrasound enhancement. Journal of Food Engineering 156: 1-9. DOI: 10.1016/j.jfoodeng.2015.01.023.

Kowalski S.J., Pawłowski A., Szadzińska J., Łechtańska J., Stasiak M. 2016. High power airborne ultrasound assist in combined drying of raspberries. Innovative Food Science and Emerging Technologies 34: 225-233. DOI: 10.1016/j.ifset.2016.02.006.

Kowalski S.J., Szadzińska J., Pawłowski A. 2015. Ultrasonic-assisted osmotic dehydration of carrot followed by convective drying with continuous and intermittent heating. Drying Technology 33(13): 1570-1580. DOI: 10.1080/07373937.2015.1012265.

Kumar C., Karim M.A., Joardder M.U.H. 2014. Intermittent drying of food products: a critical review. Journal of Food Engineering 121: 48-57. DOI: 10.1016/j.jfoodeng.2013.08.014.

Lewicki P.P. 2006. Design of hot air drying for better foods. Trends in Food Science and Technology 17: 153-163. DOI: 10.1016/j.tifs.2005.10.012.

Michalska A., Wojdyło A., Lech K., Łysiak G.P., Figiel A. 2016. Physicochemical properties of whole fruit plum powders obtained using different drying technologies. Food Chemistry 207: 223-232. DOI: 10.1016/j.foodchem.2016.03.075.

Mieszczakowska-Frąc M., Buczek M., Kruczyńska D., Markowski J. 2015. Cloudy red-fleshed apple juice production and quality. Polish Journal of Natural Sciences 30(1): 59-71.

Musielak G., Mierzwa D., Kroehnke J. 2016. Food drying enhancement by ultrasound - a review. Trends in Food Science and Technology 56: 126-141. DOI: 10.1016/j.tifs.2016.08.003.

Onwude D.I., Hashim N., Janius R., Abdan K., Chen G., Oladejo A.O. 2017. Non-thermal hybrid drying of fruits and vegetables: a review of current technologies. Innovative Food Science and Emerging Technologies 43: 223-238. DOI: 10.1016/j.ifset.2017.08.010.

Orrego C.E., Salgado N., Botero C.A. 2014. Developments and trends in fruit bar production and characterization. Critical Reviews in Food Science 
and Nutrition 54: 84-97. DOI: 10.1080/10408398.2011.571798.

Piasecka E., Uczciwek M., Konopacka D., Mieszczakowska-Frąc M., Szulc M., Bonazzi C. 2013. Effect of long-time storage on the content of polyphenols and ascorbic acid in osmo-convectively dried and osmo-freeze-dried fruits. Journal of Food Processing and Preservation 37: 198-209. DOI: 10.1111/j.1745-4549.2011.00637.x.

Rajewska K., Mierzwa D. 2017. Influence of ultrasound on the microstructure of plant tissue. Innovative Food Science and Emerging Technologies 43: 117 129. DOI: 10.1016/j.ifset.2017.07.034.

Re R., Pellegrini N., Proteggente A., Pannala A., Yang M., Rice-Evans C. 1999. Antioxidant activity applying an improved ABTS radical cation decolorization assay. Free Radical Biology and Medicine 26(9-10): 1231-1237. DOI: 10.1016/s08915849(98)00315-3.

Rodríguez Ó., Eim V., Rosselló C., Femenia A., Cárcel J.A., Simal S. 2017. Application of power ultrasound on the convective drying of fruits and vegetables: effects on quality. Journal of the Science of Food and Agriculture 98(5): 1660-1673. DOI: 10.1002/jsfa.8673.

Septembre-Malaterre A., Remize F., Poucheret P. 2018. Fruits and vegetables, as a source of nutritional compounds and phytochemicals: Changes in bioactive compounds during lactic fermentation. Food Research International 104: 86-99. DOI: 10.1016/j.foodres.2017.09.031.

Sijtsema S.J., Jesionkowska K., Symoneaux R., Konopacka D., Snoek H. 2012. Perceptions of the health and convenience characteristics of fresh and dried fruits. LWT - Food Science and Technology 49: 275-281. DOI: 10.1016/j.1wt.2012.04.027.

Siucińska K., Konopacka D. 2014. Application of ultrasound to modify and improve dried fruit and vegetable tissue: a review. Drying Technology 32: 13601368. DOI: 10.1080/07373937.2014.916719.

Siucińska K., Konopacka D., Parosa R. 2015. Preservation of highbush blueberry fruit (Vaccinium corymbosum L.) using novel ultrasound assisted drying techniques. In: Proceedings of the International Conference on Food Chemistry and Technology (FCT-2015). 16-18 November, USA, p. 39.
Siucińska K., Konopacka D., Mieszczakowska-Frąc M., Polubok A. 2016a. The effects of ultrasound on quality and nutritional aspects of dried sour cherries during shelf-life. LWT - Food Science and Technology 68: 168-173. DOI: 10.1016/j.lwt.2015.11.055.

Siucińska K., Mieszczakowska-Frąc M., Połubok A., Konopacka D. 2016b. Effects of ultrasound assistance on dehydration processes and bioactive component retention of osmo-dried sour cherries. Journal of Food Science 81(7): C1654-C1661. DOI: 10.1111/1750-3841.13368.

Szadzińska J., Kowalski S.J., Stasiak M. 2016. Microwave and ultrasound enhancement of convective drying of strawberries: experimental and modeling efficiency. International Journal of Heat and Mass Transfer 103: 1065-1074. DOI: 10.1016/j.ijheatmasstransfer.2016.08.001.

Szadzińska J., Łechtańska J., Kowalski S.J., Stasiak M. 2017. The effect of high power airborne ultrasound and microwaves on convective drying effectiveness and quality of green pepper. Ultrasonics Sonochemistry 34: 531-539. DOI: 10.1016/j.ultsonch.2016.06.030.

The Red Report: The science behind tart cherries. 2012. Cherry Marketing Institute. http://www.choosecherries.com/wp-content/uploads/2014/08/The-Red-Report.pdf (accessed October $24^{\text {th }}, 2017$ )

Wojdyło A., Figiel A., Lech K., Nowicka P., Oszmiański J. 2014b. Effect of convective and vacuum-microwave drying on the bioactive compounds, color, and antioxidant capacity of sour cherries. Food and Bioprocess Technology 7: 829-841. DOI: 10.1007/s11947-013-1130-8.

Wojdyło A., Nowicka P., Laskowski P., Oszmiański J. 2014a. Evaluation of sour cherry (Prunus cerasus L.) fruits for their polyphenol content, antioxidant properties, and nutritional components. Journal of Agricultural and Food Chemistry 62: 1233212345. DOI: 10.1021/jf504023z.

Zielinska M., Michalska A. 2016. Microwave-assisted drying of blueberry (Vaccinium corymbosum L.) fruits: drying kinetics, polyphenols, anthocyanins, antioxidant capacity, colour and texture. Food Chemistry 212: 671-680. DOI: 10.1016/j.foodchem.2016.06.003. 